\title{
Ideal leader profiles in the Icelandic business sector: Evidence of uniformity of followers' attitudes
}

\author{
Inga Minelgaité Snæbjörnsson ${ }^{1}$
}

\section{Útdráttur}

Rannsóknir á fyrirmyndar leiðtogahæfni í menningarlegu samhengi heldur vinsældum sínum par sem pað tengist skilvirkri forystu, frammistöðu fyrirtækja og niðurstöðum peirra. Rannsóknir benda til pess að félagslegir og lýðfræðilegir eiginleikar fylgjenda geti haft áhrif á pað hvað peim finnst ákjósanleg hegðun fyrirmyndar leiðtoga, sem gerir petta að mikilvægu rannsóknarefni. Heimildir gefa til kynna að kyn, menntunarstig og aldur fylgjenda eru einkenni sem hafa mest áhrif á viðhorf peirra til leiðtogahæfni. Aftur á móti gefa niðurstöður pessarar rannsóknar til kynna að fylgjendur á Íslandi hafa sameiginlegt viðhorf til fyrirmyndar leiðtogahæfni - án pess að mismunur vegna kyns, menntunarstigs eða aldurs fylgjenda hafi áhrif pegar fyrirmyndarleiðtoga er lýst. Fjallað er áhrif niðurstaðna á stjórnunarlega pætti í greininni.

\begin{abstract}
Research on the ideal leader profile in a cultural context maintains its popularity as it is related to leadership effectiveness, performance of organizations and organizational outcomes. The literature suggests that the sociodememographic characteristics of the followers might affect the preferences towards ideal leader behavior and hence, are important to investigate. This article presents the results of empirical research that was conducted in Iceland on ideal leader preferences. The literature indicates that gender, education level and the age of a follower are the characteristics that might affect attitudes the most. However, the results of the empirical research presented here indicate that followers in Iceland have uniform views towards ideal leader behavior - no difference due to the follower's gender, education level or age was indicated when describing the ideal leader. The managerial implications of the findings are discussed in the article.
\end{abstract}

JEL flokkun: M1

Keywords: leadership, Iceland, follower, diversity of followers, ideal leader profile, societal culture Íslands.

${ }^{1}$ Inga Minelgaite Snæbjörnsson er nýdoktor í viðskiptafræði við Viðskiptafræðideild Háskola

This work is licensed under a Creative Commons Attribution 4.0 License. 


\section{Introduction}

Leadership is important as it influences the effectiveness of organizational outcomes (UhlBien, Riggio, Lowe, and Carsten, 2014), and moreover is related to dealing with increasing competition and performance (Boin, 2005) and the overall effects that leaders have in society. The type of behavior that constitutes a good leader is a central question in leadership research. This question fuels continual interest in leadership research and the development of new leadership theories, and is the topic of heated academic debate.

There has been a fundamental need within management science to define both effective leadership (Andreesc and Vito, 2010) and universally effective leadership (House et al., 2004). These descriptions are useful in management practice, as they serve as guidelines for management in understanding the perceptions of the employees regarding what constitutes a desired, preferred or ideal leader. Members of a particular group or culture are more likely to interpret and evaluate situations and events in a similar manner and do so differently to those in different groups (Erez and Earley, 1993); hence, the investigation of group effects on perceived ideal leadership is of particular value in leadership research, as it can make leadership practice even more effective. Research shows that different national cultures describe the ideal leader in different ways (Littrell, 2010). Some countries have low withincountry variance while other countries show meaningful differences in terms of certain characteristics of followers when describing ideal leader behavior (Littrell et al., 2016). The investigation of diversity in follower attitudes is important for various reasons. Firstly, it helps to adjust managerial practices in regard to leadership behavior. Secondly, it provides an overview of the variety of attitudes of followers, and thus leads to a better understanding of the diversity (or uniformity) of the workforce in a country. Thirdly, it provides a basis for cultural sensitivity and a cautious attitude towards supposedly universal management practices.

Even though leadership is a universally experienced phenomenon, it is culture contingent - what constitutes a good leader depends on the particular culture/sub-culture (House et al., 2004, Mockaitis, 2005) or group of people, related to certain characteristics (e.g. gender, education) and values. Therefore this article presents empirical research conducted in Iceland about followers' attitudes towards ideal leadership. The aim of the research was twofold: first, to describe the ideal leader profile in Iceland, and second, to analyse the responses of the followers about the ideal leader profile and thereby determine the diversity of attitudes when evaluated by sociodemographic characteristics of the followers.

Considering Iceland's particular geographical situation and welfare state status, its comparatively large middle class could suggest uniformity of views. However, global trends regarding aspects such as generational differences, effects of educational level and similar characteristics could suggest a diversity of views when describing the ideal leader. Hence, assumptions regarding anticipated results are not clear and call for research and analysis of empirical data. The above-mentioned analysis will provide an overview of the specific local context in Iceland in regard to the ideal leadership, which can serve in leadership development and training.

The following sections of the article include a literature review, where the introduction to leadership theories is presented together with preferred leadership theory, followed by followers' diversity in leadership. The next part of the article presents the methodology of the empirical research. The following section presents the results of the research in the form 
of descriptive statistics and hypothesis-testing methods. The last part consists of discussion and conclusions and is mainly aimed at providing the managerial implications of research results.

\section{Literature review}

\subsection{Landscape of leadership theories}

The two main challenges in leadership literature, both of which cause problems in leadership research, are the definition of leadership and the number of competing theories in leadership. Stogdill (1974) suggested that there are "almost as many definitions of leadership as there are persons who have attempted to define the concept" (p. 259). Fleishman et al. (1992) indicate 65 different classification systems for the definition of leadership, formed through the history of leadership research, which reflect on one or more of the following aspects:

- group process (Bass and Stogdill, 1990; Zaccaro et al., 2002)

- personality perspective (Lord et al., 1986; Bryman, 1992)

- power relationship (Dansereau, Graen, and Haga, 1975)

- transformational process (Burns, 1978; Bryman, 1992)

- skills (Katz, 1955; Mumford, et. al, 2000)

- acts or behavior (Kahn and Katz, 1952; Stogdill, 1974; Blake and McCanse, 1991).

Dinh et al. (2014) suggest that 60 leadership theories are found in the literature today. The description and presentation of all of these theories is well beyond the purpose of this research thesis. Therefore, the leadership theory chosen for this research is presented below, with an indication of the rationale for this choice, together with a short description of the theory.

\subsection{Leader behavior theory and two-factor theory}

Leader behavior theory is the core leadership theory of this research. It emphasizes the behavior of a leader by focusing on what leaders do and how they act (Northouse, 2013). Leader behavior is considered as "the relatively consistent pattern of behavior that characterizes a leader" (Dubrin, 1994). Leadership behavior (or style) theory suggests that leaders engage in two types of behavior, task behaviors and relationship behaviors. The combination of these two behaviors, when influencing others, is the main focus of this leadership theory (Northouse 2013). Leader behavior theory, popularized by the Ohio State University studies (Stogdill, 1948) and the University of Michigan studies (Cartwright and Zander, 1960), continues to be one of the major leadership theories and has been a basis of or influence on - other leadership theories, such as the path-goal theory (House, 1971).

One of the most influential developments in leadership studies was the two-factor theory - task behavior (initiating structure) and relationship behavior (consideration, nurturance of followers) (Kahn and Katz, 1960; Stogdill, 1974) - which later developed into concepts of transformational and transactional leadership (see Kotter, 1990; Judge and Piccolo, 2004; Bass and Avolio, 1994). The two-factor theory is behavioral theory of leadership. The Ohio State studies considered the two factors to be independent of each other, in effect two different continua (Northouse, 2013), even though Judge and Piccolo (2004) suggested the interrelationship of the factors as a reason for studying them together. 
Concurring with this idea, Littrell (2013) elaborated on research evidence (see Avolio, 1999; Bass and Avolio, 1993; Howell and Avolio, 1993) that supports the perspective of the two factors as inter-related processes, both of which contribute to the complexity of organizational management.

As mentioned above, the two-factor behavioral theory of leadership laid the ground for considerable research in the leadership field. One of these directions was an investigation of preferred or ideal leader profiles.

\subsection{Ideal leader behavior}

Research in leadership indicates that followers have a certain "prototype" of an ideal leader. When evaluating the leader, the follower creates categories of leaders, in essence prototypes that reflect the individual's ideal leader, on the basis of personal experience (Goethals and Sorenson, 2007). In other words, a follower has an a priori attitude, a vision of how a leader should behave in general as well as in certain situations (Hogg, 2001; Goethals and Sorenson, 2007).

These prototypes of ideal leaders are important, as they are related to leader effectiveness which can be explained by leadership categorization theory (Lord and Maher, 1991). This theory suggests that a "person is more likely to be accepted as a leader if the person who is evaluating sees a good fit between a leader's expected and actual behaviour" (Littrell, 2013, p. 569). In other words, a leader is more likely to be accepted if he or she is behaving in accordance with a follower's expectations. Therefore, the ideal leader prototypes are related to actual leader behavior as a means of improving leadership effectiveness (Schyns and Schilling, 2011). Many important outcomes, such as employee attitude and evaluation of a leader, together with a leader's effectiveness, influence and productivity levels, can depend on the follower's preconception of an ideal leader (Van Quaquebeke et al., 2009; Stelmokienè and Endriulaitienè, 2015). However, one of the most important components in increasing leadership effectiveness is the ability to identify followers' expectations and needs regarding leader behavior (Mockaitis, 2005) - in other words, the ideal leader profile.

\subsection{Leadership Behavior Description Questionnaire}

The most established and widely used instrument in leadership research is the Leader Behavior Description Questionnaire XII (LBDQXII) (Northouse, 2013, p.76). The questionnaire was developed by staff at the Ohio State Leadership Studies by compiling a questionnaire from 1800 items that were condensed into 150 questions (Hemphill and Coons, 1957) and later reduced to 100 questions (Stogdill, 1963). The LBDQXII describes the behavior of an ideal leader (though it can also be used for actual leader behavior), or somebody in a leadership or supervisory position. The questionnaire consists of 100 items with Likert-type response categories. These 100 items were factor analyzed to construct 12 dimensions of leader behavior (see table below).

The literature indicates that LBDQXII is a reliable (Stogdill, 1965) and valid instrument (Halpin and Winer, 1957; Black and Porter, 1991; Selmer, 1997). The main discussion regarding preferred leader behavior today relates to whether or not those leader behavior preferences depend on context (Festekjian et al., 2014). In the research presented in this paper, the followers' sociodemographic characteristics are considered as the context, and the investigation of the uniformity or diversity of the followers' attitudes is one of the main questions. 
Table 1. Preferred Leader Behavior Dimensions Defined by the LBDQ XII

Factor 1: Representation measures to what degree the manager speaks as the representative of the group.

Factor 2: Demand Reconciliation reflects how well the manager reconciles conflicting demands and reduces disorder to system.

Factor 3: Tolerance of Uncertainty depicts to what extent the manager is able to tolerate uncertainty and postponement without anxiety or getting upset.

Factor 4: Persuasiveness measures to what extent the manager uses persuasion and argument effectively, and exhibits strong convictions.

Factor 5: Initiation of Structure measures to what degree the manager clearly defines his/her own role, and lets followers know what is expected.

Factor 6: Tolerance of Freedom reflects to what extent the manager allows followers scope for initiative, decision and action.
Factor 7: Role Assumption measures to what degree the manager actively exercises the leadership role rather than surrendering leadership to others.

Factor 8: Consideration depicts to what extent the manager regards the comfort, well-being, status and contributions of followers.

Factor 9: Production Emphasis measures to what degree the manager applies pressure for productive output.

Factor 10: Predictive Accuracy measures to what extent the manager exhibits foresight and ability to predict outcomes accurately.

Factor 11: Integration reflects to what degree the manager maintains a closely knit organization and resolves inter-member conflicts.

Factor 12: Superior Orientation measures to what extent the manager maintains cordial relations with superiors, holds weight with them, and is striving for higher status.

Source: Summarised from Stogdill (1963)

\subsection{Diversity of followers: effects of sociodemographic characteristics}

Followers' views on leadership are important and evident (Shamir, 2007). However, the literature indicates that followers' views towards leaders might differ from those in the literature, depending on the sociodemographic characteristics of the followers; the leader preferences that are most effective are gender, education level, industry of employment, and age.

\subsection{Gender}

Gender in leadership continues to trigger passionate debate among academics as well as in the popular media. It is evident that gender roles and attributes are changing with time and within societies (Twenge, 1997). In the long term, these shifts change the understanding of what is feminine, masculine or even neutral. Nevertheless, the question of whether or not men and women view things differently in today's society has not yet been resolved.

The literature indicates contradictory findings regarding gender differences in leadership styles. Some papers support the evidence of gender differences in leadership style. Even though Eagly and Johnson (1990) came to the conclusion that there were insignificant differences in leadership styles, they stress that female leaders in organizational settings tend to be more democratic and participative than men, who have a tendency towards more autocratic behavior. Rosener (1990) also found that males adopted a more 
"transactional" leadership style whereas women leaned more towards a "transformational" style of leading. This was also confirmed in a meta-analysis done by Eagly, JohannesenSchmidt, and van Engen (2003). Helgesen (1990) concluded that women prefer a "web" organization instead of a hierarchical company structure. Some studies have also shown a difference in the self-perception of male and female managers (Vinnicombe and Cames, 1998).

Other studies indicate little or no difference in leadership style among men and women. For instance, the study by Bartol (1978), the meta-analysis by Dobbins and Platz (1986) as well as Powell's (1999) findings indicated few, if any, arguments for differences in gender styles of leadership. Nevertheless, the industries where leaders work can have an impact here. In male-dominated industries, women tend to have similar leadership styles to men in those industries, and may even demonstrate a more stereotypically masculine style of leadership than males (Gardiner and Tiggemann, 1999). These findings support Kanter's (1977) conclusions, where she states that women alter their management style when in a minority, in order to lessen differences perceived by men.

Studies on the effectiveness of leadership style reveal that women and men are equally effective leaders. Differences only appear in gender evaluation: men and women were more effective in roles that were appropriate to their gender, cf. role congruence theory (Eagly, Karau and Makhijani, 1995). When investigating leader behavior preferences, research indicates that gender differences exist (Vecchio and Boatwright, 2002). Furthermore, the literature indicates that gender effects might in some cases have a greater influence on leader behavior preferences than race (Littrell and Nkomo, 2005).

It is evident that gender has become more prominent in leadership studies in recent years. It will probably remain this way even in the future, due to constantly changing environments, increasing egalitarianism in many parts of the world and technological changes. However, while attention has mainly been devoted to gendered differences in leadership research, very few studies have investigated "gendered" follower attitudes towards ideal leader behavior. Therefore, this gap is addressed in the research presented in this paper.

\subsection{Education level}

The education level of a follower has not yet received enough attention in leadership research. Very little research has been carried out on this topic, though some differences regarding the effects of education levels have been reported. For example, Vecchio and Boatwright (2002) reported that employees with higher levels of education expressed less preference for leader structuring. Education levels have been found to be negatively correlated with workers' ideal preferences for worker-centered leadership behaviors, but are positively correlated with ideal preferences for job-centered leadership behaviors (Boatwright and Forrest, 2000).

\subsection{Age}

Age in leadership literature is often discussed in the context of generational differences. Indeed, a body of research confirms that generational differences exist in leadership style (Salahuddin, 2010), which also impacts leader behavior priorities of the followers (Boatwright, 2000). Hofstede, Hofstede and Minkov (2010) suggested that societal values could change over time, which could lead to somewhat different values among different 
generations in the same country. Similarly, Inglehart (1997) found some differences among generations worldwide.

To sum up, sparse or contradicting evidence of the effects of gender, industry, education level and age suggest the need to investigate possible influences on ideal leader behavior preferences.

\section{Methodology}

\subsection{Survey instrument}

The field survey method was used in order to investigate preferred leader profile in Iceland. The survey instrument that was used, LBDQXII (Leader Behavior Description Questionnaire XII, see below), is a component of the Preferred Leader Behavior Across Cultures project (CCCC - Centre for Cross Cultural Comparisons). This project is discussed at length in Littrell (2013). The overarching project wherein the data of this study was collected focuses on leader behavior preferences of employed business people.

\subsection{Leadership Behavior Description Questionnaire}

The theoretical approach adopted in this research study is the Ohio State Theory of Leadership, operationalized by the Leader Behavior Description Questionnaire version XII (LBDQXII, see http://fisher.osu.edu/research/lbdq/). As to the choice of LBDQXII in this particular research, the conclusion of the literature review should be mentioned. After conducting a literature review, the LBDQXII was found to be the only non-experimental questionnaire designed to research ideal leader behavior, with well-established cross-cultural sample bases and studies published by competent teams. The English version of the survey is publically available from Ohio State University.

\subsection{Preparation of the Survey Instrument}

The survey was administered in Icelandic, after the standard double-blind translation process recommended by Brislin (1980). Preparation and adaptation of the original questionnaire followed general guidelines, formulated by Littrell for the international consortium of the Study on Leadership and Values project, namely:

- 2 translations from English to Icelandic, implemented by native speakers;

- 2 back translations to English from Icelandic, implemented by native speakers;

- 2 focus group studies, to discuss and validate the translations.

This preparation procedure of the survey instrument is aimed at quality assurance of the translations and adaptation of the instrument. Other implemented actions in this process are specified below.

The English version of the questionnaire was translated by two independent native speakers (Icelandic). The translated versions were then compared and unified by another native speaker. The unified version of the translated questionnaire was subsequently sent to the other two native speakers. The back translation versions were then compared with the original version of the questionnaire. Minor inconsistencies were addressed, and the translated versions were revised. 
The finalized translated version of the questionnaire was sent to six Icelandic native speakers. They were asked to answer the questionnaires and be prepared to give their general impression of it, mark specific questions they had difficulty in understanding, and provide other comments that could help researchers to improve the instrument. Then each group met at an agreed place and time to discuss the questionnaire. In the focus group meetings, participants were asked to provide feedback. After providing the feedback, the English version of the questionnaire was presented, in order to help improve the items in question.

Afterwards, one more focus group was organized. This group received the same version of the questionnaire as the first group. As before, after giving feedback on the questionnaire, group members were presented with its English version, as well as the suggestions made by the previous group. Focus groups were conducted in Icelandic. Each focus group discussion was recorded by video camera and voice-recorded, with their consent, to ensure the ability to adequately analyze the material later. Two focus group reports were produced as a result.

Corrections were applied to the translated versions according to the feedback received during focus group discussions. Then the improved versions of the questionnaires were sent to linguists for comments regarding style and grammar.

The last phase of questionnaire preparation included at least five academics from business studies, who provided feedback regarding the text of the questionnaire.

\subsection{Sampling and recruitment of participants and sampling strategy}

The population in this study consists of employed business people in Iceland. As organizational structure can influence employees' preferences towards managerial leader behavior, a specific sector - private companies - is the focus of this research.

In this research study, the subjects were systematic random samples (Tashakkori and Teddlie, 2003) of business people, drawn from Iceland.

\subsection{Recruitment of participants}

The questionnaire was distributed in cooperation with SA - Business Iceland (www.sa.is). SA is represents a wide range of Icelandic businesses and its member associations include about 2,000 businesses. The organization accounts for about $70 \%$ of all salaried employees in the Icelandic labour market. SA sent an invitation to all of its member companies, encouraging them to distribute the online questionnaire among their employees. Two weeks later, SA sent a reminder email to all the members of SA, encouraging them to participate in the survey. As a precautionary backup in order to encourage and maintain a response rate consistent with the resources available to the researcher, every tenth company in the list provided by SA was contacted to indicate the importance of the study and to encourage participation. Even though such a strategy might be considered as contamination of random sampling, the analysis of responses (by date) indicates that contacting the companies did not affect the response rate in any manner.

\subsection{Sampling, data cleaning and calculations}

\subsubsection{Sample size}

The online questionnaire was accessed and answered to different degrees by 373 respondents. After the elimination of unreliable responses (procedure specified below) and after data cleaning procedures, the data set was left with 155 responses to be used in further analysis. 
This research represents the case, where population size is not known, as population is all employed people in all companies which are members of SA. However, not knowing how many of the companies actually distributed questionnaire to their employees, makes it impossible to determine population size (as level of analysis is individual). Therefore, the common practise in cross-cultural research was applied, namely satisfying the condition of more than 50 responses and homogeneity of sample (Hofstede, Minkov and Vinken, 2008; Hair, Erson, Tatham and Black, 1995). Both conditions were satisfied in this research.

\subsubsection{Data cleaning process}

It is critical to clean collected data before analyzing it. The CCCC consortium established criteria to eliminate respondents who have apparently taken a careless approach to completing the survey, discriminated among their values, skipped too many items, or responded in ways suggesting deliberate misrepresentation, as discussed in Littrell (2010).

\subsubsection{Cleaning LBDQXII response data}

For the total number of missing items, after cleaning the data, the process consisted of placing subjects into two groups, i.e. those who had missing data and those who did not, and carrying out sequential multivariate analyses of variance for groups. The results indicated that groups which had completed $90 \%$ of the total items had multivariate population mean estimates that were not significantly different, at a 0.05 level of probability, from those with $100 \%$ completion rates. Thus the minimum $90 \%$ completion criterion was used to include subjects in analyses.

After subjects with fewer than $90 \%$ complete items had been eliminated from dimension scores and after cleaning the data, the process involved placing subjects into two groups, i.e. those who had missing data and those who did not, and carrying out Games-Howell posthoc tests for each dimension. Subsequent iterations were run, adding subjects who had one missing item per dimension, then two, then three. The results indicated that groups with $80 \%$ of the items complete for each dimension had population means estimates that were not significantly different, $\mathrm{p}<0.05$, from the group with no missing items. That criterion was used to include subjects in analyses.

1. Subjects who did not complete 90 of the 100 items were dropped from the analysis.

2. Subjects who did not complete $80 \%$ of the items that define a dimension were assigned a blank (missing data) for the calculation of that dimension for those particular subjects.

3. Subjects who had an identifiable pattern of responses were dropped from the analysis, for example repeated response strings of $4,5,4,5$, or 1, 2, 3, 4, 5, 1, 2, 3, 4, 5, etc.

\subsubsection{Calculation of dimensiosn: LBDQXII factors}

Conversion of $\mathrm{A}-\mathrm{E}$ values of the questionnaire and calculations of the LBDQXII factors were done following the Manual for the Leader Behavior Description Questionnaire - Form XII (Stogdill, 1963). Factors are defined by the average of the scores of different numbers of items specified in the table below. 
Table 2. Structure of the Factors

\begin{tabular}{clc}
\hline Number of factor & Items & Items in total \\
\hline F1 & $1,11,21,31,41$ & 5 \\
F2 & $51,61,71,81,91$ & 5 \\
F3 & $2,12,22,32,42,52,62,72,82,92$ & 10 \\
F4 & $3,13,23,33,43,53,63,73,83,93$ & 10 \\
F5 & $4,14,24,34,44,54,64,74,84,94$ & 10 \\
F6 & $5,15,25,35,45,55,65,75,85,95$ & 10 \\
F7 & $6,16,26,36,46,56,66,76,86,96$ & 10 \\
F8 & $7,17,27,37,47,57,67,77,87,97$ & 10 \\
F9 & $8,18,28,38,48,58,68,78,88,98$ & 10 \\
F10 & $9,29,49,59,89$ & 5 \\
F11 & $19,39,69,79,99$ & 5 \\
F12 & $10,20,30,40,50,60,70,80,90,100$ & 10 \\
\hline
\end{tabular}

Source: Stogdill, 1963

\subsection{Validity and reliability of the survey}

In their extensive meta-analysis of the survey instruments developed by the Ohio State Studies team, Judge, Piccolo and Iles (2004) found that all the survey instruments had significant predictive validity for leader success. Moreover, LBDQXII has "the highest validities averaged across the overarching dimensions of Consideration and Initiating Structure of their exhaustive array of studies reviewed" (Littrell, 2010, p. 169). Vecchio (1987) and Kerr et al. (1974) concluded LBDQXII to be a widely accepted index of leader behavior, based on its psychometric qualities (e.g. reliability and construct validity).

Table 3. Internal Validity of LBDQXII Factors of the Research Project Sample

\begin{tabular}{clc}
\hline Number of factor & Items & Cronbach $\alpha$ \\
\hline F1 & $1,11,21,31,41$ & 0.685 \\
F2 & $51,61,71,81,91$ & 0.516 \\
F3 & $2,12,22,32,42,52,62,72,82,92$ & 0.509 \\
F4 & $3,13,23,33,43,53,63,73,83,93$ & 0.817 \\
F5 & $4,14,24,34,44,54,64,74,84,94$ & 0.772 \\
F6 & $5,15,25,35,45,55,65,75,85,95$ & 0.712 \\
F7 & $6,16,26,36,46,56,66,76,86,96$ & 0.629 \\
F8 & $7,17,27,37,47,57,67,77,87,97$ & 0.757 \\
F9 & $8,18,28,38,48,58,68,78,88,98$ & 0.527 \\
F10 & $9,29,49,59,89$ & 0.759 \\
F11 & $19,39,69,79,99$ & 0.787 \\
F12 & $10,20,30,40,50,60,70,80,90,100$ & 0.670 \\
\hline
\end{tabular}

Typically, the rule of thumb for Cronbach alphas is: 0.9: Excellent, 0.8: Good, 0.7: Acceptable, 0.6: Questionable, 0.5: Poor, and <0.5: Unacceptable. However, Schmitt (1996) empirically demonstrated that there is no sacred level of alphas. Canales, Tejeda-Delgado and Slate (2008) found the LBDQXII scales from data in the USA to be reliable with Cronbach alphas ranging from 0.67 to 0.95 , and noted 85 studies from 62 universities that found the 
LBDQXII to be a reliable and valid instrument. Hence, Cronbach $\alpha$ presented in Table 3 can be considered acceptable.

\subsection{Ethical considerations}

Ethical considerations were made following the recommendations of Bryman and Bell (2007). The invitation to participate in the research contained information about the purpose of the research initiators and institutions that they represent, along with contact information should any questions arise. The electronic link to the survey was distributed. Respondents were informed that research results would be presented in summarized form, and therefore there would be no risk of personal harm or negative consequences based on one's own opinions. A respondent's decision to answer the research questions is considered his/her consent to allow researchers to use his/her answers for purposes of the research. Emails and requests for additional information about the purpose of the research and the affiliations of the researchers were answered with honesty and transparency.

\subsection{Data analysis methods}

Statistical Package for the Social Sciences 14.0 (SPSS) software was used in data analysis. The literature suggests that the choice of analytical methods (parametric or non-parametric) should first of all depend on three factors: normality of distribution of the sample, type of data, and sample size (Kuzon et al., 1996). Below, all three criteria are described with respect to this particular research.

\subsection{Normality tests}

Skewness and kurtosis analysis with z-values outside +/-1.96 interval range (Doane and Seward, 2011), Shapiro-Wilk's test with $\mathrm{p}<0.05$ (Shapiro and Wilk, 1965) and visual inspection of histograms, normal Q-Q plots and box plots allow one to conclude the samples are not normally distributed.

Shapiro-Wilk's test (1965) is considered in recent literature to be one of the most powerful tests (Razali and Wah, 2011, p.32). Moreover, it is suitable for sample size $3<\mathrm{n}<5000$ (Royston, 1995). Therefore, this particular test is chosen in the analysis.

The literature suggests the use of non-parametric analysis methods for samples that are not normally distributed (Jamieson, 2004). However, Norman (2010) suggests that parametric methods can be utilized without concern for "getting the wrong answer", as he provides evidence that "many studies, dating back to the 1930s consistently show that parametric statistics are robust with respect to violations of these assumptions" (p. 625). Moreover, when investigating ideal leader profiles in New Zealand and China, Littrell (2010) used both parametric and non-parametric tests and concluded a lack of significant difference in the results using both methods. Therefore, the decision was made to use parametric methods in the analysis of the data of this research.

\subsection{Type of data and data analysis methods}

LBDQXII dimensions were measured with a Likert-type scale, which is an ordinal type of scale.

After careful consideration, the following data analysis methods were chosen in order to achieve the aims of this research:

1. Descriptive analysis of the sample in order to:

a) describe sample characteristics,

b) describe preferences for leader behavior. 
2. Hypothesis testing:

a) Gender does not affect LBDQXII preferences. Test: one-way analysis of variance for gender (One-way ANOVA).

b) Level of education does not affect LBDQXII preferences. Correlation and ANOVA analysis were thought appropriate after considering other methods of analysis.

c) Age of the respondent does not affect LBDQXII preferences. Correlation analysis was used to investigate the relationship between age and LBDQXII preference.

\section{$4 \quad$ Results}

\subsection{Descriptive analysis}

Table 4 presents the gender, age, education and religion of the respondents in the surveys. The gender of the respondents in the survey closely resembles the situation in Icelandic firms, where approximately 70\% of managers are males (Statistics Iceland, 2015).

The largest age group in the sample is the 50-59 age range. Part of the reason for this is the above-mentioned large number of participants in the Icelandic sample who were at the highest management level $-68 \%$ of the participants had finished a university degree.

Table 4. Sociodemographic Characteristics of the Sample

\begin{tabular}{|c|c|c|}
\hline & & Iceland \\
\hline \multirow[t]{2}{*}{ Gender } & Male, $\%$ & 74 \\
\hline & Female, \% & 26 \\
\hline \multirow[t]{5}{*}{ Age } & $<29$ & 2 \\
\hline & $30-39$ & 18 \\
\hline & $40-49$ & 27 \\
\hline & $50-59$ & 40 \\
\hline & $>60$ & 13 \\
\hline \multirow[t]{12}{*}{ Education } & High School & 6 \\
\hline & NF Secondary & 8 \\
\hline & School & \\
\hline & Secondary School & 15 \\
\hline & NF Professional & 3 \\
\hline & School & \\
\hline & Professional School & 14 \\
\hline & NF Bachelor's & 8 \\
\hline & Bachelor's degree & 21 \\
\hline & NF Master's & 2 \\
\hline & Master's degree & 23 \\
\hline & Doctoral degree & 2 \\
\hline \multirow[t]{8}{*}{ Religion } & Catholic & 3 \\
\hline & Lutheran & 68 \\
\hline & Orthodox & 1 \\
\hline & Protestant & 12 \\
\hline & Buddhist & 1 \\
\hline & Agnostic/Atheist & 13 \\
\hline & Chinese traditional & 0 \\
\hline & Judaism & 0 \\
\hline
\end{tabular}




\begin{tabular}{llc}
\hline & Islam & 1 \\
Occupational groups & African tribal & 1 \\
& Worker & 3 \\
& Craftsman & 13 \\
& Office employee & 18 \\
& Specialist & 18 \\
& Middle & 1 \\
& management & \\
& Top management & 47 \\
\hline NF-abbreviation for "Not finished" &
\end{tabular}

Data from official statistics reveals that $74 \%$ of the population in Iceland are Lutherans (Statistics Iceland, 2015), and thus it is not surprising that $68 \%$ of participants belong to this group. With regard to job level, as already mentioned, the sample has an unusually high number of responses from highest-level management. This could be considered a limitation; however, it should be mentioned that analysis of variance (ANOVA) was conducted in order to investigate whether top management in the sample has statistically significant different preferences towards leader behavior compared to lower levels of employees. Analyses indicated no significant differences among the groups in the Icelandic sample. Based on the above reasons, top management was not eliminated from the sample.

The table below shows information on the size of the firms, the industrial sectors to which they belong and the type of ownership. Most of the respondents work in private companies $(89 \%)$, which was the intention in regard to the data type.

\begin{tabular}{llc}
\multicolumn{2}{l}{ Table 5. Information on Firms of Respondents' } & Employment \\
\hline \multirow{2}{*}{ Company size } & Micro (up to 10) & $\%$ \\
& Small (up to 50) & 15 \\
& Medium (up to 250) & 20 \\
& Large (more than 250) & 27 \\
Industrial & Wholesale and retail & 38 \\
sectors & & \\
& Other services, including & 14 \\
& consultancy & 40 \\
& Financial services & \\
& Marketing and sales & 4 \\
& Manufacturing & 9 \\
Ownership type & Mixed ownership & 34 \\
& NGO & 3 \\
& Private (SC, JSC) & 3 \\
& Public & 89 \\
& & 5
\end{tabular}

To conclude: The respondents participating in the research represent a variety of companies of differing sizes and types of industry.

The primary aim of this research was to describe ideal leader profiles in Iceland. Figure 1 indicates respondents' preferences. 
Figure 1. Preferences towards ideal leader behavior, evaluated by 12 LBDQXII dimensions

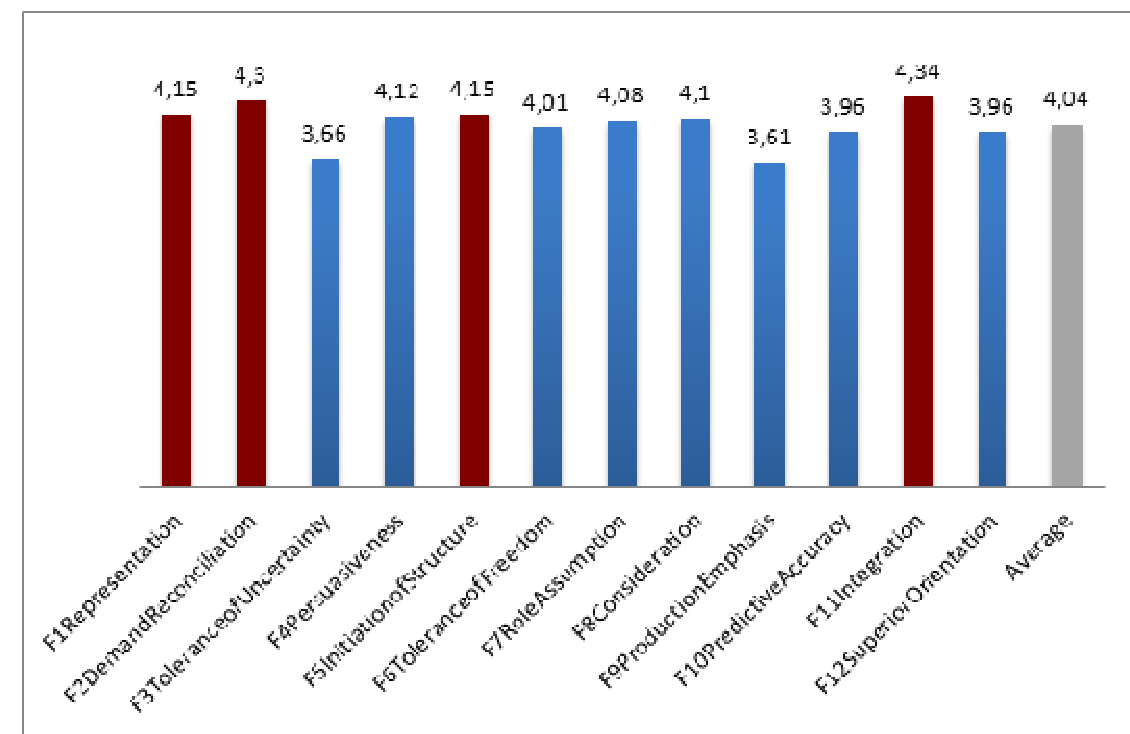

As indicated in Figure 1, for people employed in the business field in Iceland, the most important aspects of leader behavior are Integration, Demand reconciliation, Representation, and Initiation of structure.

\subsection{Hypothesis testing}

The second aim of this research was to determine the diversity of attitudes of the followers towards ideal leader behavior, when evaluated by the sociodemographic characteristics of the followers. Three hypotheses were formulated and statistical methods chosen in order to test the hypotheses.

a) Gender does not affect LBDQXII preferences. Test: one-way analysis of variance for gender (One-way ANOVA).

One-way ANOVAs were performed, which indicated that there are no gender differences $(p>0.05)$ for any of the 12 factors among men and women. Therefore, the hypothesis regarding no gender differences in followers' attitudes towards ideal leader behavior is accepted.

Table 6. A One-way ANOVA on gender differences.

\begin{tabular}{|c|c|c|c|c|c|c|}
\hline & & Sum of Squares & DF & Mean Square & $\mathrm{F}$ & Sig. \\
\hline F1 Representation & Between Groups & .031 & 1 & .031 & .124 & .726 \\
\hline $\begin{array}{l}\text { F2 Demand } \\
\text { Reconciliation }\end{array}$ & Between Groups & .215 & 1 & 215 & .615 & .434 \\
\hline $\begin{array}{l}\text { F3 Tolerance of } \\
\text { Uncertainty }\end{array}$ & Between Groups & .005 & 1 & .005 & .031 & .860 \\
\hline F4 Persuasiveness & Between Groups & .173 & 1 & .173 & .760 & .385 \\
\hline $\begin{array}{l}\text { F5 Initiation of } \\
\text { Structure }\end{array}$ & Between Groups & .042 & 1 & .042 & .252 & 616 \\
\hline $\begin{array}{l}\text { F6 Tolerance of } \\
\text { Freedom }\end{array}$ & Between Groups & .080 & 1 & .080 & .560 & .455 \\
\hline
\end{tabular}




\begin{tabular}{|c|c|c|c|c|c|c|}
\hline & & Sum of Squares & DF & Mean Square & $\mathrm{F}$ & Sig. \\
\hline $\begin{array}{l}\text { F7 Role } \\
\text { Assumption }\end{array}$ & Between Groups & .014 & 1 & .014 & .054 & .816 \\
\hline F8 Consideration & Between Groups & .112 & 1 & .112 & .541 & .463 \\
\hline $\begin{array}{l}\text { F9 Production } \\
\text { Emphasis }\end{array}$ & Between Groups & .011 & 1 & .011 & .073 & .787 \\
\hline $\begin{array}{l}\text { F10 Predictive } \\
\text { Accuracy }\end{array}$ & Between Groups & .032 & 1 & .032 & .163 & .687 \\
\hline F11 Integration & Between Groups & .192 & 1 & .192 & .802 & .372 \\
\hline $\begin{array}{l}\text { F12 Superior } \\
\text { Orientation }\end{array}$ & Between Groups & .009 & 1 & .009 & .056 & .813 \\
\hline
\end{tabular}

b) The level of education does not affect LBDQXII preferences. Correlation analysis and ANOVA analysis were chosen as appropriate, after considering other methods of analysis.

As mentioned in the literature review, the level of education can influence followers' perceptions in regard to what constitutes ideal leader behavior. Therefore, the second hypothesis investigates the effect of education level on followers' preferences towards ideal leader behavior.

One can argue that years of education is an indicator of a progressive continuum of development of skills that can be applied in the business environment. Therefore, a correlation analysis, followed by a one-way ANOVA analysis of variance, was used to reject or confirm the hypothesis.

Table 7. Correlation analysis: Education and LBDQXII dimensions

\begin{tabular}{lcccccccccccc}
\hline & $\mathrm{F} 1$ & $\mathrm{~F} 2$ & $\mathrm{~F} 3$ & $\mathrm{~F} 4$ & $\mathrm{F5}$ & $\mathrm{F} 6$ & $\mathrm{~F} 7$ & $\mathrm{~F} 8$ & $\mathrm{~F} 9$ & $\mathrm{~F} 10$ & $\mathrm{~F} 11$ & $\mathrm{~F} 12 \mathrm{~S}$ \\
\hline Pearson Correlation & -.067 & -.038 & -.115 & -.121 & $-.238^{* *}$ & -.039 & -.031 & -.123 & -.144 & -.031 & -.060 & -.151 \\
Sig. (2-tailed) & .404 & .636 & .151 & .131 & .003 & .628 & .696 & .124 & .071 & .698 & .458 & .058 \\
$\mathrm{~N}$ & 158 & 158 & 158 & 158 & 158 & 158 & 158 & 158 & 158 & 158 & 158 & 158 \\
\hline
\end{tabular}

Correlation analysis indicated that there is a negative correlation (significance level 0.01) between education level and F5 (Initiation of Structure); the more educated the person, the less importance he/she attaches to the ideal leader's engagement in behaviors related to a clear definition of employees' roles and the role of manager. This can be explained by the fact that the more educated people are likely to have a better understanding about their own role in the organization and they may not find this to be an essential feature of an ideal leader.

Table 8. A one-way ANOVA analysis. F5 Initiation of Structure

\begin{tabular}{lccccc}
\hline Levene Statistic & DF1 & DF2 & Sig. \\
\hline 1.240 & 9 & & 148 & .275 \\
\hline & Sum of Squares & DF & Mean Square & F & Sig. \\
\hline Between Groups & 2.265 & 9 & .252 & 1.571 & .129 \\
\hline
\end{tabular}


However, a one-way ANOVA test, with $p>0.05$, failed to show a significant difference in preferences towards ideal leader behavior between different educational levels of respondents. In other words, respondents' education level did not influence LBDQXII preferences in the sample. Based on this, the second hypothesis is accepted.

a) The age of the respondent does not affect LBDQXII preferences.

Correlation analysis was used to investigate the relationship between age and LBDQXII preferences and confirm/reject the third hypothesis.

Table 9. Correlation analysis: Age and LBDQXII dimensions

\begin{tabular}{|c|c|c|c|c|c|c|c|c|c|c|c|c|c|}
\hline & & $\mathrm{F} 1$ & $\mathrm{~F} 2$ & F3 & F4 & F5 & F6 & F7 & F8 & F9 & F10 & F11 & F12 \\
\hline \multirow[t]{3}{*}{ Age } & $P$ & .127 & .016 & -.053 & .097 & -.075 & .055 & .104 & .145 & .062 & .053 & -.007 & .080 \\
\hline & Sig. & .115 & .842 & .512 & .227 & .352 & .494 & .200 & .072 & .443 & .516 & .930 & .325 \\
\hline & $N$ & 155 & 155 & 155 & 155 & 155 & 155 & 155 & 155 & 155 & 155 & 155 & 155 \\
\hline
\end{tabular}

The analyses presented above indicated no effects on means for the preferred leader behavior dimension due to the age of participants. Therefore, the third hypothesis is accepted. The conclusion is that age does not affect leader behavior preferences in Iceland.

To recapitulate on the findings of this previous section: In Iceland, followers have very similar preferences towards preferred leader behavior, independent of gender, education level and age.

\section{$5 \quad$ Discussion and conclusions}

The overall conclusion of this research is that Integration, Demand reconciliation, Representation, and Initiation of structure are the most desired behaviors of the ideal leader, as described by the followers in Iceland. Moreover, the followers in Iceland have uniform attitudes when describing the ideal leader behavior - the follower's gender, education level or age had no effect on the description of an ideal leader.

The conclusion deals with contextualization and relating this to managerial practices. First of all, an elaboration on ideal leader preferences.

The results of the research indicate that the most desired characteristics of a leader within the Icelandic cultural context are Integration, Demand reconciliation, Representation, and Initiation of structure. In other words, as seen by followers, the ideal leader first and foremost has to be able to maintain a closely knit organisation and resolve inter-member conflicts (Stogdill, 1963). These characteristics indicate the need of the followers to experience a team spirit in the organization and the sense of unity. However, ensuring such an environment at work is perceived to be the leader's prerogative and his/her most important task. These findings are also in line with those of GLOBE (House et al., 2004), which indicated team-oriented leadership to be one of the most desired qualities in Nordic countries. Integration is a dimension of leadership which describes leader's social skills (Peterson and Seligman, 2004). Therefore, it is evident that for followers employed in the business field in Iceland, a leader's social competence is considered as the most important skill for effective leadership. 
The second most important characteristic is Demand reconciliation, which describes how well a leader reconciles conflicting demands and reduces disorder (Stogdill, 1963). These characteristics correspond to information use and problem solving, as described in Fleishman's et al. (1992) taxonomy. This is the second most important characteristic for Icelanders, and the second one to include the ability to solve conflicts or conflicting situations, even though demand reconciliation describes a more individual level or personality attributes of the leader (Peterson and Seligman, 2004). Demand reconciliation implies that the ideal leader for Icelanders is the one who first and foremost is able to prevent, reduce and solve various conflicts at both the organizational level and outside the organization. Therefore, when considering leadership effectiveness development, managerial leaders in Iceland can focus on conflict-solving competences and training.

Another two prioritized characteristics were Representation and Initiation of structure. Representation applies to the degree that the leader speaks as the representative of the group (Stogdill, 1963); it is a personality attribute (Peterson and Seligman, 2004) and is similar to "charismatic leadership", as presented in the GLOBE research (House et al., 2004). It is clear, as the GLOBE findings indicate, that charismatic leadership is desired in Nordic countries (House et al., 2004). However, it is worth mentioning that the GLOBE study found charismatic leadership to be universally desired leadership, and therefore it can be argued that this preference indicates universal attributes of desired leadership but does not necessarily highlight context specifics in Iceland.

Initiation of structure is about being able to clearly define the leader's own role within the organization, as well as letting followers know what is expected from them (Stogdill, 1963). The priority given to this characteristic can be explained by the need for clarity, which typically allows clearer evaluation of performance and better workflow. This implies that some leadership styles (e.g. distributed leadership) will not necessarily be successful as seen by followers. Nevertheless, it also implies that a certain formality level (but not necessarily hierarchy) will contribute positively to the effectiveness of leadership when it comes to job description. The managerial implication based on the above is that the ideal leader is seen as the one who proactively delegates and assigns resources, while also possessing a good sense of the overall direction of organizational progress. Project management and human resource management competences could be related as positively contributing to the initiation of structure behaviour.

One of the main aims of this article was to determine whether followers have diverse attitudes when describing the ideal leader, due to the follower's gender, education level and age, as suggested by the literature. The results of the research presented above indicate the lack of such diversity, or in other words a uniformity of attitudes. These results imply that, on the one hand, it could be easier to determine effective leadership behaviors and, most importantly, to apply them due to the uniformity of followers' attitudes and the synchronized idea about what constitutes a good leader. On the other hand, it might imply that Icelandic expatriate leaders will be less prepared to deal with leadership expectations in countries where follower attitudes are very diverse (e.g. Lithuania, see Snaebjornsson, 2016), where a highly flexible leadership style needs to be applied. This implies that Icelandic managers intending to work abroad should improve their competences in diversity management as part of their leadership training. Furthermore, similar potential dangers can be faced in the local market too. The Icelandic work market is increasingly changing and is forecasted to change even more, due to the high need of workers in certain sectors. This implies the need for managerial leaders to be competent in diversity management and 
furthermore, having cultural intelligence skills. Having more diverse management teams (in terms of gender, age and experience) could help to more easily achieve effectiveness in diversity management and increasingly diverse attitudes of the managers.

This research gives a basis for future research regarding ideal leadership. Future research of interest would include, but not be limited by: Icelandic expatriates and their leadership styles in other cultural contexts, global expatriate leadership styles in the Icelandic context, in relation to the Icelandic profile of an ideal leader, and furthermore, it would be of practical use, to investigate quantitatively the actual leadership style of Icelandic managerial leaders in relation to the Icelandic ideal leader profile, in order to determine, weather Icelandic managers "fit" the main trends of the ideal leader, as seen by Icelandic followers.

\section{References}

Andreescu, V., \& Vito, G. F. (2010). An exploratory study on ideal leadership behaviour: the opinions of American police managers. International Journal of Police Science $\mathcal{E}$ Management, 12(4), 567-583.

Avolio, B. J. (1999). Full Leadership Development: Building the Vital Forces in Organizations. Thousand Oaks: Sage.

Bartol, K. M. (1978). The sex structuring of organizations: A search for possible causes. Academy of Management Review, 3(4), 805-815.

Bass, B. M., \& Avolio, B. J. (1993). Transformational leadership and organizational culture. Public Administration Quarterly, 17(1),12-121.

Bass, B. M., \& Avolio, B. J. (1994). Transformational leadership and organizational culture. The International Journal of Public Administration, 17(3-4), 541-554.

Bass, B. M., \& Stogdill, R. M. (1990). Bass \& Stogdill's Handbook of Leadership: Theory, Research, and Managerial Applications. New York: Simon and Schuster.

Black, J. S., \& Porter, L. W. (1991). Managerial Behaviors and Job Performance: A Successful Manager in Los Angeles May Not Succeed in Hong Kong. Journal of International Business Studies, 22(1), 99-113.

Blake, R. R., \& McCanse, A. A. (1991). Leadership Dilemmas--Grid Solutions. Houston, TX, USA: Gulf Professional Publishing.

Boatwright, K. J., \& Forrest, L. (2000). Leadership preferences: The influence of gender and needs for connection on workers' ideal preferences for leadership behaviors. Journal of Leadership \& Organizational Studies, 7(2), 18-34.

Boin, A. (2005). The politics of crisis management: Public leadership under pressure. Cambridge University Press: UK.

Brislin, R. W. (1980). Translation and content analysis of oral and written material. Handbook of Cross-Cultural Psychology, 2(2), 349-444.

Bryman, A. (1992). Charisma and Leadership in Organizations. London: Sage Publications.

Burns, J. M. (1978). Leadership. New York, USA: Harper and Row/HarperCollins.

Canales, M., Tejeda-Delgado, C., \& Slate, J. R. (2008). Superintendents/principals in small rural school districts: A qualitative study of dual roles. American Educational Research Association (AERA). 
Cartwright, D., \& Zander, A. (1960). Leadership and group performance: Introduction. In D. Cartwright \& A. Zander (Eds.), Group Dynamics: Research and Theory (3rd ed.) (pp.487510), Evanston, IL: Row Peterson.

Dansereau, F., Graen, G., \& Haga, W. J. (1975). A vertical dyad linkage approach to leadership within formal organizations: A longitudinal investigation of the role making process. Organizational Behaviour and Human Performance, 13(1), 46-78.

Dinh, J. E., Lord, R. G., Gardner, W. L., Meuser, J. D., Liden, R. C., \& Hu, J. (2014). Leadership theory and research in the new millennium: Current theoretical trends and changing perspectives. The Leadership Quarterly, 25(1), 36-62.

Doane, D. P., Seward, L. E. (2011). Measuring Skewness. Journal of Statistics Education, 19 (2), $1-18$.

Dobbins, G. H., \& Platz, S. J. (1986). Sex differences in leadership: how real are they? Academy of Management Review, 11(1), 118-127.

DuBrin, A. J. (1994). Contemporary Applied Management: Skills for Managers. Illinois: Irwin Professional Publishing.

Eagly, A. H., \& Johnson, B. T. (1990). Gender and leadership style: A meta-analysis. Psychological Bulletin, 108(2), 233.

Eagly, A. H., Johannesen-Schmidt, M. C., \& Van Engen, M. L. (2003). Transformational, transactional, and laissez-faire leadership styles: a meta-analysis comparing women and men. Psychological Bulletin, 129(4), 569.

Eagly, A. H., Karau, S. J., \& Makhijani, M. G. (1995). Gender and the effectiveness of leaders: a meta-analysis. Psychological Bulletin, 117(1), 125.

Erez, M., \& Earley, P. C. (1993). Culture, self-identity, and work. New York: Oxford University Press.

Festekjian, A., Tram, S., Murray, C. B., Sy, T., \& Huynh, H. P. (2014). I See Me the Way You See Me: The Influence of Race on Interpersonal and Intrapersonal Leadership Perceptions. Journal of Leadership \& Organizational Studies, 21(1), 102-119.

Fleishman, E. A., Mumford, M. D., Zaccaro, S. J., Levin, K. Y., Korotkin, A. L., \& Hein, M. B. (1992). Taxonomic efforts in the description of leader behavior: A synthesis and functional interpretation. The Leadership Quarterly, 2(4), 245-287.

Gardiner, M., \& Tiggemann, M. (1999). Gender differences in leadership style, job stress and mental health in male- and female-dominated industries. Journal of Occupational and Organizational Psychology, 72(3), 301-315.

Goethals, G. R., \& Sorenson, G. J. (Eds.). (2007). The Quest for a General Theory of Leadership. Location: Edward Elgar Publishing.

Halpin, A. W., \& Winer, B. J. (1957). A factorial study of the leader behavior descriptions. In R.M. Stogdill \& A.E. Coons (eds.), Leader behavior: Its description and measurement. Columbus, OH: Ohio State University,(pp. 39-51).

Helgesen, S. (1990). The Female Advantage: Women's Ways of Leading. New York.

Hemphill, J. K., \& Coons, A. E. (1957). Development of the leader behavior description questionnaire. In R. M. Stogdill \& A. E. Coons (Eds.), Leader Behavior: Its Description and Measurement (pp. 6, 38). Columbus: Ohio State University. Bureau of Business Research.

Hofstede, G., Hofstede, G. J., \& Minkov, M. (2010). Cultures and Organizations, Software of the Mind. Intercultural Cooperation and Its Importance for survival. USA: McGraw-Hill.

Hogg, M. A. (2001). A social identity theory of leadership. Personality and Social Psychology Review, 5(3), 184-200. 
House, R. J. (1971). A path goal theory of leader effectiveness. Administrative Science Quarterly, 16(3), 321-339.

House, R. J., Hanges, P. J., Javidan, M., Dorfman, P. W., \& Gupta, V. (Eds.). (2004). Culture, Leadership, and Organizations: The GLOBE Study of 62 societies. Thousand Oaks: Sage Publications.

Howell, J. M., \& Avolio, B. J. (1993). Transformational leadership, trans-actional leadership, locus of control, and support for innovation: Key predictors of consolidated-businessunit performance. Journal of Applied Psychology, 78(6), 891.

Inglehart, R. (1997). Modernization and Postmodernization: Cultural, Economic, and Political Change in 43 Societies. Princeton, NJ: Princeton University Press.

Jamieson, S. (2004). Likert scales: how to (ab) use them. Medical Education, 38(12), 1217-1218.

Judge, T. A., Piccolo, R. F., \& Ilies, R. (2004). The forgotten ones? The validity of consideration and initiating structure in leadership research. Journal of Applied Psychology, 89(1), 36.

Kahn, R. L., \& Katz, D. (1952). Leadership practices in relation to productivity and morale. Institute for Social Research: University of Michigan.

Kahn, R. L., \& Katz, D. (1960). Leadership practices in relation to productivity and morale. In D. Cartwright \& A. Zander (Eds.), Group Dynamics. New York: Harper \& Row.

Kanter, R. M. (1977). Men and Women of the Corporation (Vol. 5049 of Harper torchbooks). USA: Basic books.

Katz, R. L. (1955). Skills of an effective administrator. Harvard Business Review, 33(1), 33-42.

Kerr, S., Schriesheim, C. A., Murphy, C. J., \& Stogdill, R. M. (1974). Toward a contingency theory of leadership based upon the consideration and initiating structure literature. Organizational Behavior and Human Performance, 12(1), 62-82.

Kotter, J. P. (1990). What Leaders Really Do. Harvard Business Review, May/June, 103-111.

Kuzon Jr., W. M., Urbanchek, M. G., \& McCabe, S. (1996). The seven deadly sins of statistical analysis. Annals of Plastic Surgery, 37(3), 265-272.

Littrell, F. R. (2013). Explicit leader behaviour: a review of literature, theory development, and research project results. Journal of Management Development, 32(6), 567-605.

Littrell, R. F. (2010). Comparative Value Priorities of Chinese and New Zealand Businesspeople and Their Relationships to Preferred Managerial Leader Behaviour. PhD thesis, Auckland University of Technology. http://aut.re searchgateway.ac.nz/handle/10292/1198.

Littrell, R. F., \& Nkomo, S. M. (2005). Gender and race differences in leader behaviour preferences in South Africa. Women in Management Review, 20(8), 562-580.

Littrell, R.F., \& Snaebjornsson, I.M. (2016). Comparison of Managerial Leadership Behavior Preferences Across Nationalities, Industries, and Gender. Conference paper at Academy of International Business (2016), New Orleans.

Lord, R. G., De Vader, C. L., \& Alliger, G. M. (1986). A meta-analysis of the relation between personality traits and leadership perceptions: An application of validity generalization procedures. Journal of Applied Psychology, 71(3), 402.

Lord, R. G., Maher, K. J. (1991). Leadership and Information Processing: Linking Perceptions and Performance (Vol. 1). Cambridge, MA, USA: Unwin Hyman.

Mockaitis, A.I. (2005). A Cross-Cultural Study of Leadership Attitudes in Three Baltic Sea Region Countries. International Journal of Leadership Studies, 1 (1), 44-63.

Mumford, M. D., Zaccaro, S. J., Harding, F. D., Jacobs, T. O., \& Fleishman, E. A. (2000). Leadership skills for a changing world: Solving complex social problems. The Leadership Quarterly, 11(1), 11-35. 
Norman, G. (2010). Likert scales, levels of measurement and the "laws" of statistics. Advances in Health Sciences Education, 15(5), 625-632.

Northouse, P. G. (2013). Leadership. Theory and Practice (6th ed.). USA: Sage Publications.

Peterson, C., \& Seligman, M. E. (2004). Character strengths and virtues: A handbook and classification. New York: Oxford University Press.

Powell, G. (Eds.) (1999). Handbook of Gender. Thousand Oaks, CA, USA: Sage Publications.

Razali, N. M., Wah, Y. B. (2011). Power comparisons of Shapiro-Wilk, Kolmogorov-Smirnov, Lilliefors and Anderson-Darling tests. Journal of Statistical Modeling and Analytics, 2(1), 21-33.

Rosener, J. (1990). How women lead. Harvard Business Review, 68(6), 119-125.

Royston, J. P. (1995). Shapiro-Wilk normality test and P-value. Applied statistics, 44(4), 547551.

SA, Business Employers' Association (n.d.). Retrieved from www.sa.is.

Salahuddin, M. M. (2010). Generational differences impact on leadership style and organizational success. Journal of Diversity Management, 5(2), 1.

Schmitt, M. (1996). Uses and abuses of coefficient alpha. Psychological Assessment, 8(4), 350353.

Schyns, B., \& Schilling, J. (2011). Implicit leadership theories: Think leader, think effective? Journal of Management Inquiry, 20(2), 141-150.

Selmer, J. (1997). Differences in leadership behaviour between expatriate and local bosses as perceived by their host country national subordinates. Leadership $\mathcal{E}$ Organization Development Journal, 18(1), 13-22.

Shamir, B. (2007). From Passive Recipients to Active Co-producers: Followers' Roles in the Leadership Process. Follower-centered Perspectives on Leadership: A Tribute to the Memory of James R. Meindl (pp. 9-39). Greenwich: IAP.

Shapiro, S. S., Wilk, M. B. (1965). An analysis of variance test for normality (complete samples). Biometrika, 52(3/4), 591-611.

Snaebjornsson, I. M. (2016). Leadership in Iceland and Lithuania: A followercentric perspective (PhD dissertation). Iceland: Haskolaprent.

Statistics Iceland (2015). Populations by Religious and Life Stance Organizations 1998-2015. Retrieved from http://www.statice.is/?PageID=1180.

Stelmokienè, A., Endriulaitiene, A. (2015). Vadovavimo efektyvumo vertinimas: psichologiniai aspektai. Vilnius: Versus aureus.

Stogdill, R. M. (1948). Personal factors associated with leadership: A survey of the literature. The Journal of Psychology, 25(1), 35-71.

Stogdill, R. M. (1963). Manual for the Leader Behaviour Description Questionnaire-Form XII: An Experimental Revision. Ohio State University: Bureau of Business Research, College $\mathrm{f}$ Commerce and Administration.

Stogdill, R. M. (1965). Managers, Employers [i.e. Employees], Organizations: a Study of 27 Organizations (No. 125). Ohio State University: Bureau of Business Research, Division of Research, College of Commerce and Administration.

Stogdill, R.M. (1974). Handbook of Leadership: A Survey of Theory and Research. New York: Free Press.

Teddlie, C., \& Tashakkori, A. (2003). Major issues and controversies in the use of mixed methods in the social and behavioral sciences. In C. Teddlie \& A. Tashakkori (Eds.), Handbook of Mixed Methods in Social \& Behavioral Research (pp. 3-50). USA: Sage Publications. 
Twenge, J. M. (1997). Changes in masculine and feminine traits over time: A meta-analysis. Sex Roles, 36(5-6), 305-325.

Uhl-Bien, M., Riggio, R. E., Lowe, K. B., \& Carsten, M. K. (2014). Followership theory: A review and research agenda. The Leadership Quarterly, 25(1), 83-104.

Van Quaquebeke, N., Zenker, S., \& Eckloff, T. (2009). Find out how much it means to me! The importance of interpersonal respect in work values compared to perceived organizational practices. Journal of Business Ethics, 89(3), 423-431.

Vecchio, R. P. (1987). Situational Leadership Theory: An examination of a prescriptive theory. Journal of Applied Psychology, 72(3), 444.

Vecchio, R. P., \& Boatwright, K. J. (2002). Preferences for idealized styles of supervision. The Leadership Quarterly, 13(4), 327-342.

Vinnicombe, S., \& Cames, I. (1998). A study of the leadership styles of female and male managers in ten different nationality banks, using the personal attributes questionnaire. International Review of Women in Leadership, 4(2), 24-33.

Zaccaro, S. J., Rittman, A. L., \& Marks, M. A. (2002). Team leadership. The Leadership Quarterly, 12(4), 451-483. 